\title{
APLIKASI INSTAGRAM DALAM MENINGKATKAN EKSISTENSI EKO NUGROHO
}

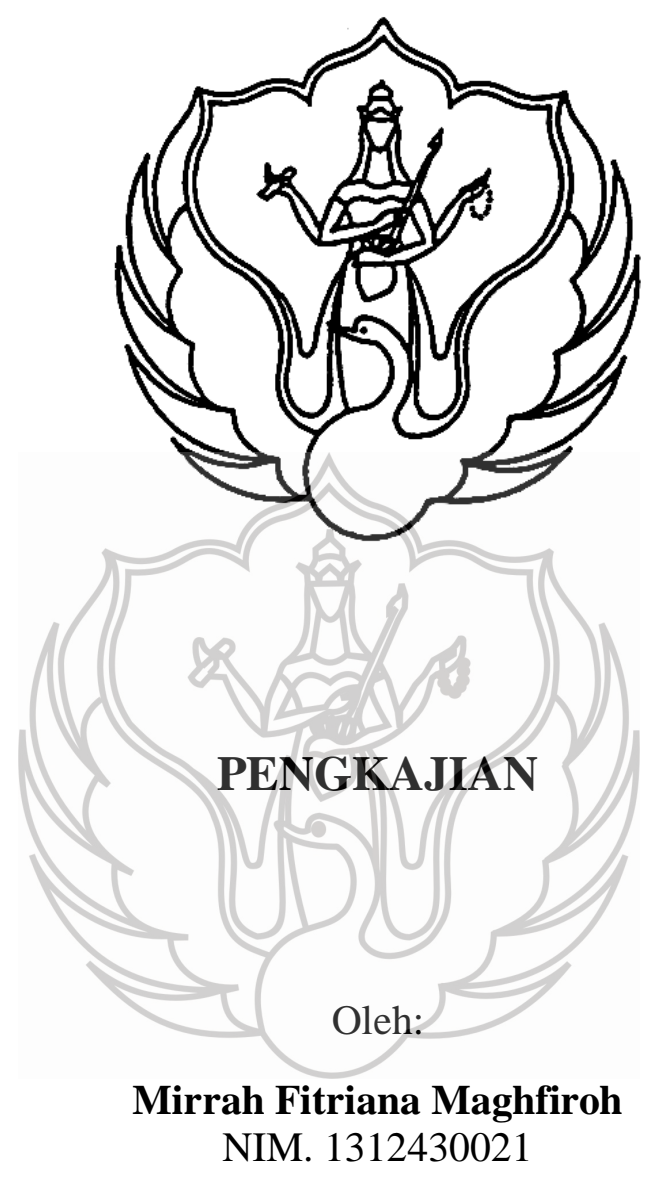

Tugas Akhir ini diajukan kepada Fakultas Seni Rupa Institut Seni Indonesia Yogyakarta Sebagai salah satu syarat untuk memperoleh gelar sarjana dalam bidang Seni Rupa Murni 2017 
Tugas Akhir Pengkajian Seni berjudul:

Aplikasi Instagram Dalam Meningkatkan Eksistensi Eko nugroho diajukan oleh Mirrah Fitriana Maghfiroh, NIM 1312430021, Program Studi Seni Rupa Murni, Jurusan Seni Murni, Fakultas Seni Rupa Institut Seni Indonesia Yogyakarta, telah dipertanggungjawabkan di depan Tim Penguji Tugas Akhir pada tanggal 13 Juli 2017.

Pembimbing I

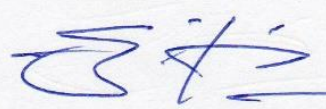

Drs.Syafruddin, M.Hum.

NIP 195408021981031004

Pembimbing II

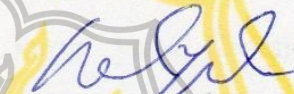

Nadiyah Tlinnikmah, S.Sn., M.A.

NIP 197904122006042001

Cognate/Anggota

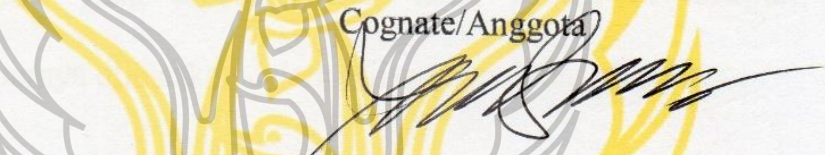

Warsono, S.Sn., M.A.

NIP 197605092003121001

Ketua Jurusan/

Program Studi/Ketua/Anggota

Dekan Fakultas Seni Rupa

Lnstitue Seni Indonesia Yozyakarta

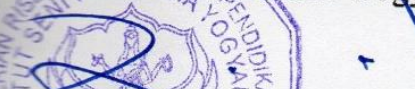

$\rightarrow 30-1$

Dr. Suastiwi, M.Des.

NIP 195908021988032002

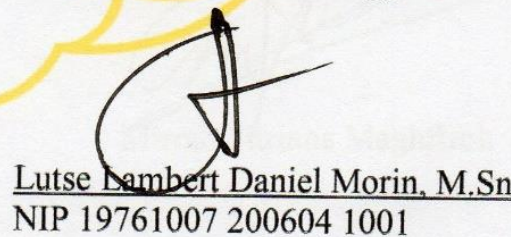

\section{UPT Perpustakaan ISI Yogyakarta}




\section{PERNYATAAN KEASLIAN}

Saya yang bertanda tangan tangan di bawah ini:

$\begin{array}{ll}\text { Nama } & : \text { Mirrah Fitriana Maghfiroh } \\ \text { NIM } & : 1312430021 \\ \text { Jurusan/Minat Utama : Seni Rupa Murni/Seni Grafis }\end{array}$

Dengan ini menyatakan bahwa skripsi ini adalah hasil pekerjaan saya sendiri dan di dalamnya tidak terdapat karya yang pernah diajukan untuk memperoleh gelar kesarjanaan di suatu perguruan tinggi dan lembaga pendidikan lainnya. Pengetahuan yang diperoleh dari hasil penerbitan maupun yang belum/bukan, sumbernya dijelaskan dalam tulisan dan daftar pustaka.

Yogyakarta, 16 Juni 2017

Mirrah Fitriana Maghfiroh

\section{UPT Perpustakaan ISI Yogyakarta}




\section{MOTO DAN PERSEMBAHAN}

\section{MOTO:}

Jadikanlah masa lalu sebagai pelajaran untuk masa depan. Karena semua cerita pasti ada hikmah dibaliknya.

" Maka ingatlah kepada Ku, niscaya Aku akan ingat kepadamu, Bersyukurlah kepada Ku, Dan janganlah kamu ingkar kepada Ku “.

( Qs. Al Baqarah : 152)

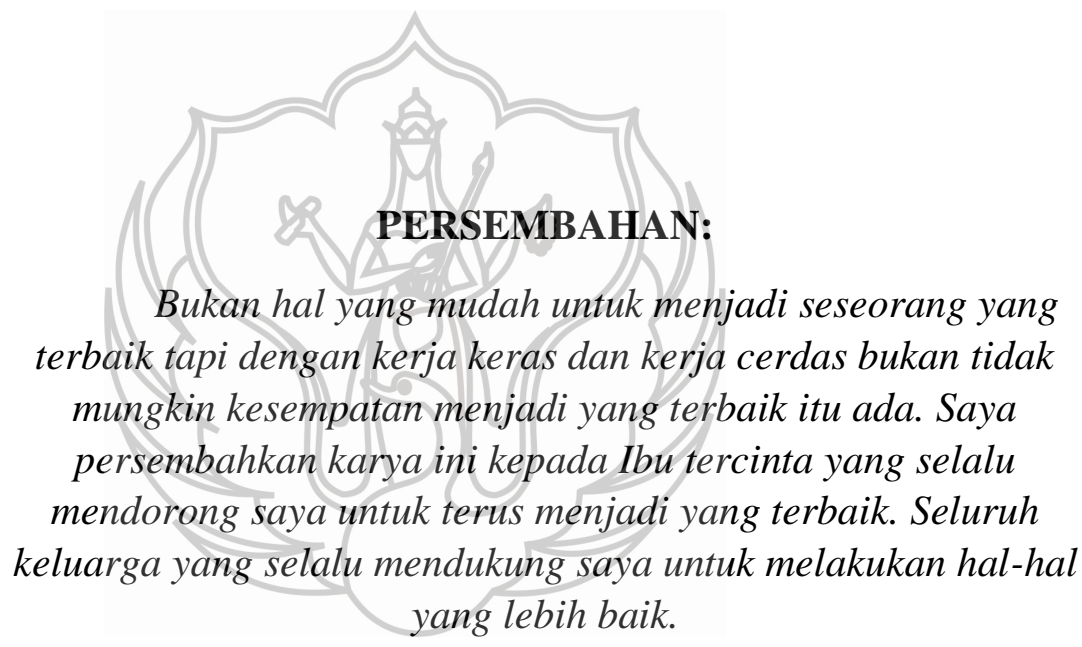

\section{UPT Perpustakaan ISI Yogyakarta}




\section{KATA PENGANTAR}

Puji dan syukur kepada Tuhan Yang Maha Esa atas berkat dan rahmatNya yang melimpah sehingga penulis dapat menyelesaikan skripsi yang berjudul Aplikasi Instagram Dalam Meningkatkan Eksistensi Eko Nugroho.

Penulis menyadari bahwa selama proses penulisan skripsi penulis telah dibantu oleh banyak pihak. Oleh karena itu, penulis ingin mengucapkan terima kasih kepada:

1. Tuhan Yang Maha Esa, karena berkat rahmat, karunia, serta kuasa-Nya sehingga memberikan sebuah ide yang luar biasa hingga diberikan kemampuan untuk merealisasikan sebuah penelitian ini. Berkat Kuasa-Nya lah penulis mendapatkan bantuan dari/beberapa pihak yang ikhlas membantu hingga selesainya penulisan.

2. Orang tua yang selalu memberi semangat dan doa. Ibu Sri Kanatun,S.Pd., yang telah berkorban materi dan waktunya untuk mendukung penulis dalam menyelesaikan kuliah, dan Bapak Achmad Najib Suroso (Alm) yang telah mendoakan penulis dari sisi Allah SWT.

3. Lutse Lambert Daniel Morin, S.Sn., M.Sn., selaku Ketua Jurusan Seni Murni. Terimakasih atas semua dukungan yang diberikan kepada penulis,

4. Satrio Hari Wicaksono, S.Sn., M.Sn., Sekretaris Jurusan Seni Murni yang telah membantu penulis dalam proses pengumpulan skripsi,

5. Drs. Syafruddin, M.Hum., Dosen Pembimbing I yang telah mendukung, memberi masukan dan kritikan, serta membantu penulis selama proses penyusunan skripsi,

\section{UPT Perpustakaan ISI Yogyakarta}


6. Nadiyah Tunnikmah, S.Sn., M.A., Dosen Pembimbing II yang juga telah mendukung, memberi masukan dan kritikan, serta membantu penulis selama proses penyusunan skripsi,

7. Setyo Priyo Nugroho, M.Sn., Dosen Wali yang telah mendukung dan membantu penulis sehingga penulis selama proses kuliah sampai proses penyusunan skripsi,

8. Eko Nugroho, selaku narasumber yang merupakan seniman rupa dan pemilik akun@ekonugroho_studio yang telah mengizinkan penulis untuk melakukan penelitian skripsi,

9. Seluruh narasumber dalam penelitian ini,

10. Seluruh dosen Seni Murni yang telah memberi ilmunya kepada penulis,

11. Seluruh keluarga besar yang selalu memberi dukungan selama kuliah,

12. Gilang Abdi Pamungkas, S.Sn, yang selalu mendampingi dan memberi semangat serta membantu penulis selama proses penulisan skripsi,

13. Teman-teman Jurusan Seni Murni, SEREMIS, rekan-rekan berkarya, dan Saraswati Drum Corps. Terimakasih untuk waktu berproses selama ini.

14. Teman-teman kampus yang tidak dapat penulis cantumkan satu per satu.

Penulis menyadari bahwa penelitian ini masih jauh dari sempurna, oleh karena itu, penulis menerima berbagai kritik dan saran yang bersifat membangun dari semua pihak.

Penulis,

Mirrah Fitriana Maghfiroh 


\section{DAFTAR ISI}

HALAMAN JUDUL ..................................................................... i

LEMBAR PENGESAHAN …......................................................... ii

PERNYATAAN KEASLIAN ................................................................. iii

MOTO DAN PERSEMBAHAN ............................................................... iv

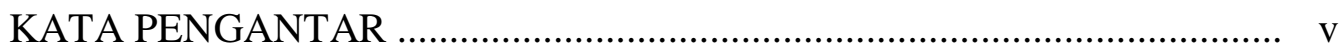

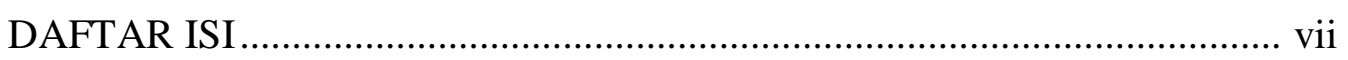

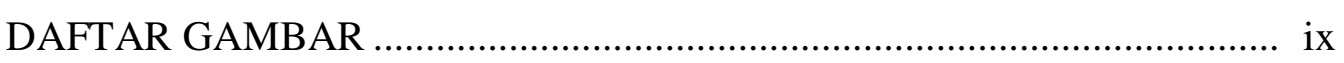

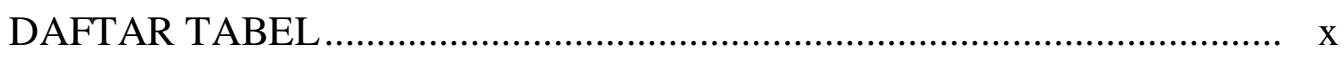

\section{BAB I. PENDAHULUAN}

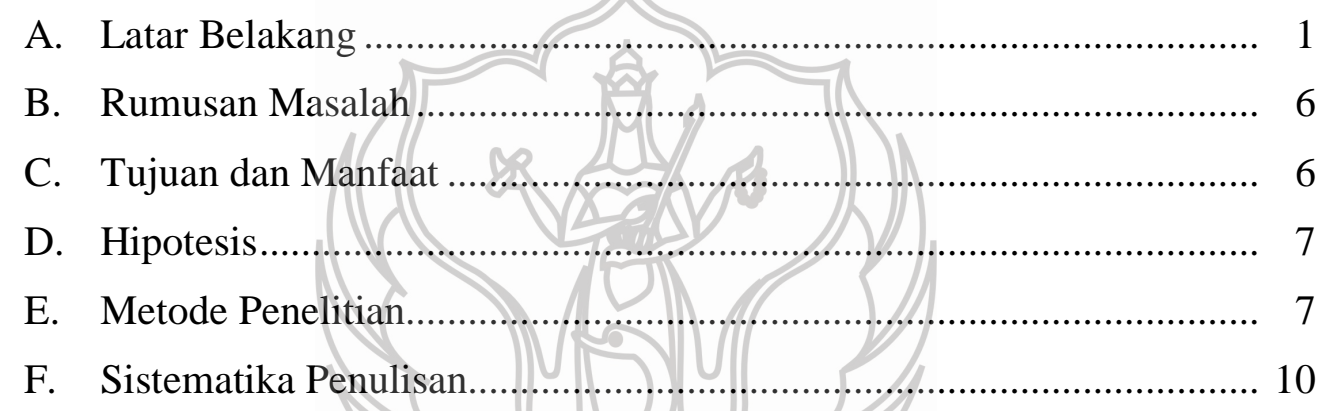

BAB II. LANDASAN TEORI

A. Komunikasi Untuk Meningkatkan Apresiasi ........................................ 11

1. Tujuan Komunikasi ................................................................. 12

2. Konteks Komunikasi .................................................................. 13

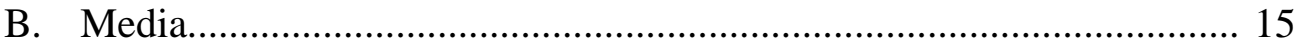

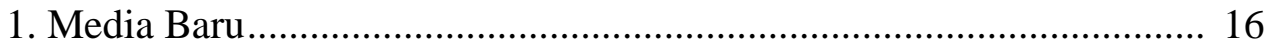

2. Media Sosial

2.1. Pengertian Media Sosial.......................................................... 19

2.2. Perkembangan Media Sosial ...................................................... 21

C. Instagram

1. Pengertian Instagram............................................................... 22

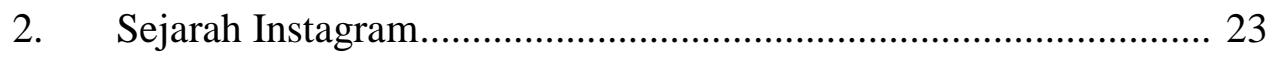

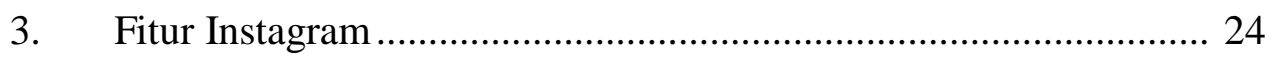


4. Keunggulan dan Pengaruh Instagram ......................................... 28

D. Eksistensi

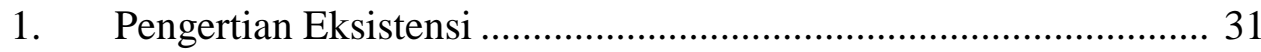

2. Faktor-Faktor yang Memengaruhi Eksistensi Diri....................... 32

3. Ciri-Ciri Dari Individu yang Memiliki Eksistensi Diri................... 34

4. Eksistensi Manusia di Dunia Maya dan Dunia Nyata ................... 35

4.1. Eksistensi Diri di Dunia Maya ..................................................... 36

4.2. Eksistensi Diri di Dunia Nyata.................................................. 37

\section{BAB III. PENYAJIAN DATA DAN ANALISIS DATA}

A. Penyajian Data

1. Strategi Eko Nugroho Dalam Publikasi ........................................... 39

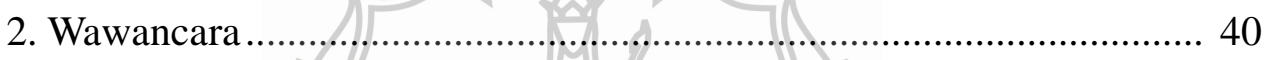

3. Tanggapan Responden Melalui Kuesioner di Instagram .................... 43

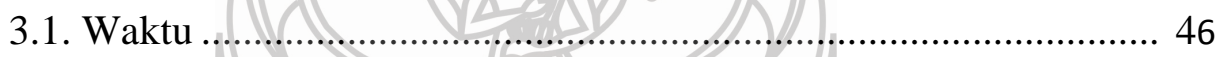

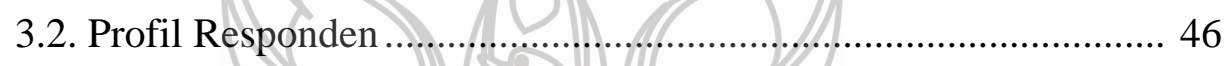

3.3. Pernyataan Responden ............................................................. 50

4. Perkembangan Akun Instagram Eko Nugroho Sejak Tahun

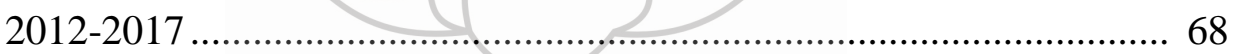

B. Analisis Data

1. Eksistensi Eko Nugroho di Dunia Nyata ............................................ 70

2. Eksistensi Eko Nugroho di Dunia Maya............................................. 74

3. Dialogis Eksistensi Eko Nugroho......................................................... 76

BAB IV. PENUTUP

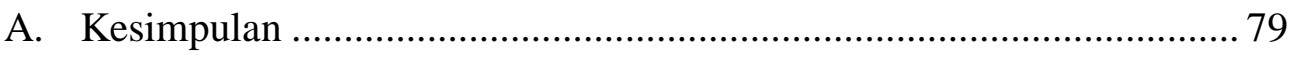

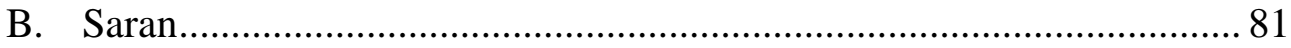

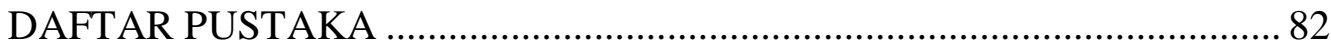

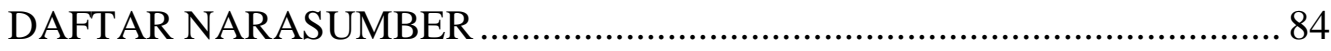

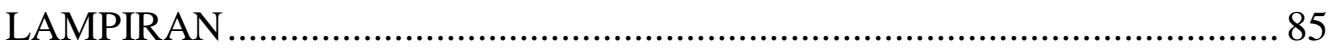




\section{DAFTAR GAMBAR}

Gambar 1.Tampilan Akun Instagram Milik Eko Nugroho ............................... 5

Gambar2. Diagram Negara Paling Populer di Instagram...................................2 29

Gambar 3. Persentase Jenis Kelamin Responden .............................................4 47

Gambar 4. Persentase Usia Responden ............................................................ 48

Gambar 5. Persentase Pendidikan Responden .................................................... 48

Gambar 6. Persentase Pekerjaan Responden ................................................... 49

Gambar 7. Persentase Responden yang Mengenal Eko Nugroho..........................55

Gambar 8. Persentase Sumber Responden Mengenal Eko Nugroho .....................55

Gambar 9. Persentase Responden yang Menggemari Eko Nugroho ....................56

Gambar 10. Persentase Responden yang Telah Menghadiri Pameran Eko

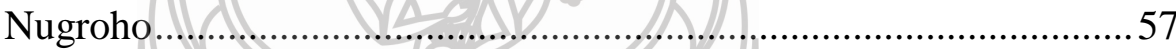

Gambar 11. Persentase Responden/Aktif Pengguna Instagram .............................. 58

Gambar 12. Persentase Responden Pengikut Akun Eko Nugroho .......................58

Gambar 13. Persentase Responden yang Mengikuti Unggahan Eko Nugroho .....59

Gambar 14. Persentase Responden yang Memberi Tanda Suka pada Unggahan

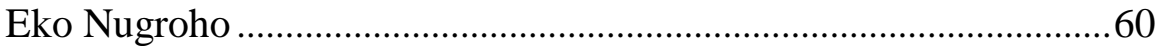

Gambar 15. Persentase Kelayakan Eko Nugroho Sebagai Referensi .....................61

Gambar 16. Beberapa Tanggapan Responden Dari Pernyataan Nomor 13 ..........62 62

Gambar 17. Persentase Orisinilitas Karya Eko Nugroho ......................................63

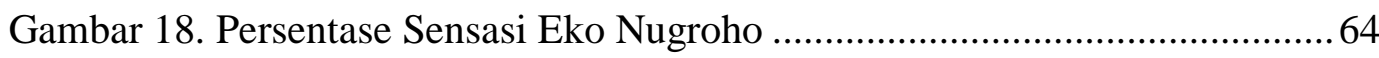

Gambar 19. Beberapa Tanggapan Responden Dari Pernyataan Nomor 16 ..........65

Gambar 20. Persentase Predikat Eko Nugroho ....................................................67

Gambar 21. Persentase Kemampuan Eko Nugroho Dalam Konsep/Ide

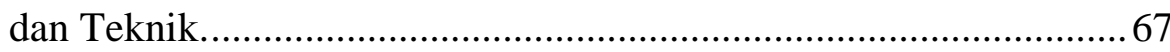

Gambar 22. Foto Pertama Akun @ekonugroho_studio ............................................ 75 
Tabel 1. Kelebihan dan Kekurangan Media..................................................... 15

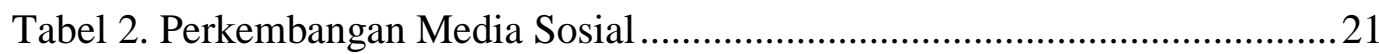

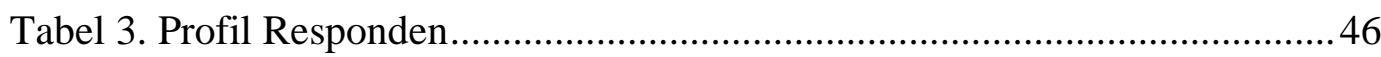

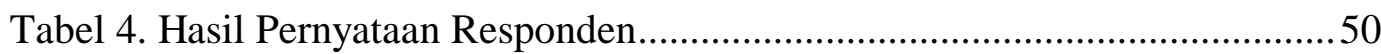

Tabel 5. Tabel Perkembangan Eksistensi Eko Nugroho di Instagram ...................68

Tabel 6. Pameran Tunggal Tingkat Nasional................................................. 71

Tabel 7. Pameran Bersama Tingkat Nasional .................................................. 71

Tabel 8. Penampilan Seni Tingkat Nasional …................................................... 71

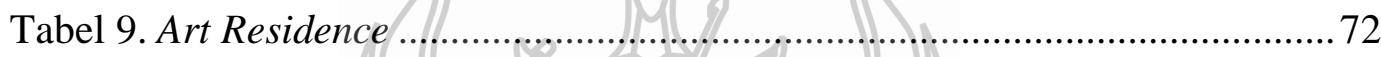

Tabel 10. Pameran Bersama Tingkat Internasional, ......................................... 72

Tabel 11. Penampilan Seni Tingkat Internasional .......................................... 73

\section{UPT Perpustakaan ISI Yogyakarta}




\section{BAB I}

\section{PENDAHULUAN}

\section{A. Latar Belakang}

Seni rupa merupakan salah satu cabang kesenian yang mengacu pada bentuk visual. Seni rupa jika ditinjau dari segi fungsi terhadap masyarakat atau kebutuhan manusia, seni rupa secara teoritis dibagi menjadi dua kelompok, yaitu seni murni (fine art) dan seni terapan (applied art $)^{l}$.

Seni Rupa Murni adalah kelompok karya seni rupa yang salah satu tujuannya untuk memenuhi kebutuhan spiritual, artinya bahwa kelahiran karya seni tersebut lahir dari adanya ungkapan atau ekspresi jiwa. Seni rupa yang bertujuan seperti itu bukan lagi merupakan kebutuhan praktis bagi masyarakat tetapi hanya mengejar nilai yang dimanfaatkan dalam lingkungan seni itu sendiri atau disebut seni untuk seni.

Sebuah karya seni apapun tidak akan tercipta tanpa ada pembuatnya, begitu juga dengan karya seni murni. Pencipta karya seni murni pada umumnya disebut seniman.

"Ada dua pengertian arti seniman, diartikan sebagai nama profesi seseorang dalam menciptakan atau menyusun bentuk karya seni. Seniman juga dapat diartikan sebagai manusia yang mengalami proses kreativitas atau proses imajinasi, yaitu proses interaksi antara persepsi memori dan persepsi luar."2

${ }^{1}$ Dharsono Soni Kartika, Seni Rupa Modern, Bandung: Rekayasa Sains, 2017, hal. 32

${ }^{2}$ Ibid, hal. 21

\section{UPT Perpustakaan ISI Yogyakarta}


Seseorang disebut seniman jika telah berkecimpung di dunia seni dan telah menghasilkan banyak karya seni, baik itu dibidang seni rupa, seni pertunjukan, maupun seni media rekam. Spesifikasi juga penting untuk menunjukkan keunggulannya.

Dalam dunia seni rupa Indonesia mulai marak seniman yang memanfaatkan media sosial dengan maksimal, salah satunya Instagram, yang memungkinkan untuk mendongkrak karir dan popularitas karya. Pencarian eksistensi di dunia seni rupa dengan pameran di galeri penting jika ingin dikenal, namun sasarannya masih terbatas hanya di lingkup daerah sekitar tempat diadakan pameran atau komunitas tertentu. Pemanfaatan media sosial Instagram akan membuat eksistensi seorang seniman semakin dikenal oleh berbagai kalangan dari masyarakat lokal hingga mancanegara, hal tersebut tentu mampu/mendongkrak eksistensi seniman.

Media sosial adalah medium di internet yang memungkinkan pengguna merepresentasikan dirinya maupun berinteraksi, bekerja sama, berbagi, berkomunikasi, dengan pengguna lain, dan membentuk ikatan sosial secara virtual ${ }^{3}$. Menurut Van Dijk (2013), media sosial adalah platform (program) media yang memfokuskan pada eksistensi pengguna yang memfasilitasi mereka dalam beraktivitas maupun berkolaborasi ${ }^{4}$. Pemanfaatan media sosial dalam seni rupa saat ini akan membantu para 
seniman rupa untuk lebih mudah berinteraksi dengan masyarakat yang mengapresiasinya, selain itu jika seniman-seniman rupa lebih aktif dan kreatif dalam mengolah akun-akun di media sosial nama mereka akan semakin dikenal. Tidak dipungkiri jika masyarakat zaman sekarang semakin selektif, mereka lebih tertarik dengan akun media sosial yang interaktif.

Media sosial yang saat ini populer di kalangan masyarakat salah satunya adalah media sosial Instagram. Media ini mempunyai spesifikasi penggunaan dengan foto atau video yang berisi banyak informasi. Kata Instagram sendiri berasal dari kata Insta, yang berarti instan, dan Gram yang diambil dari kata telegram. Dilansir dari situs resmi Instagram, pengertian Instagram adalah salah satu media sosial yang menyenangkan dan unik untuk berbagi/ cerita hidup melalui serangkaian gambar dan video..$^{5}$ Pengertian Instagram menurut Atmoko dalam bukunya Instagram Handbook adalah seperti berikut:

"Instagram adalah sebuah aplikasi berbagi foto yang memungkinkan pengguna mengambil foto, menerapkan filter digital, dan membagikannya ke berbagai layanan jejaring sosial, termasuk milik Instagram sendiri. ${ }^{\prime 6}$

Instagram didirikan oleh Kevin Systrom pada tahun 2010, saat ini menjabat sebagai CEO dan Co-Founder Instagram dan Mike Krieger sebagai CTO dan Co-Founder Instagram. Saat ini Instagram telah mengalami banyak perkembangan pada fasilitasnya, diantaranya bisa WIB

${ }^{5}$ https://www.instagram.com/about/faq/ diakses tanggal 22 Februari 2017 pukul 09.00

${ }^{6}$ Dwi Bambang Atmoko, Instagram Handbook, Jakarta: Media Kita, 2012, hal.4

\section{UPT Perpustakaan ISI Yogyakarta}


menampilkan slide foto hingga 10 foto dalam sekali unggahan, mengunggah video selama 60 detik, menampilkan video secara langsung yang lebih dikenal dengan istilah live sehingga yang sedang dilakukan saat itu bisa disaksikan secara langsung, dan instastory merupakan fasilitas untuk mengunggah foto atau video terbaru dan hanya bertahan selama 24 jam setelah itu akan hilang secara otomatis. Instagram adalah sebuah media interaksi sosial yang berbasis teknologi digital. Selain menampilkan hasil gambar dan video dari para penggunanya instagram juga berhasil membuat semua orang berinteraksi melalui gambar dan video dari satu pengguna ke pengguna lainnya. Fasilitas tersebut banyak dimanfaatkan oleh pengguna Instagram.

Instagram saat ini banyak dimanfaatkan oleh para seniman sebagai media untuk mempublikasikan karya-karyanya. Melalui Instagram eksistensi para pengguna akunnya bisa meningkat dengan cepat, begitu juga dengan seniman rupa. Eksistensinya akan semakin meningkat jika ditambah dengan penggunaan yang aktif, desain yang menarik, dan karya yang unik yang mampu menarik perhatian masyarakat umum maupun komunitas tertentu.

Salah satu seniman rupa yang sudah banyak dikenal masyarakat di Indonesia adalah Eko Nugroho. Eko Nugroho dikenal dengan karyakarya yang dibuat dengan cara dibordir atau ciri khas lainnya sering memanfaatkan ruang pamer secara maksimal mulai dari atap hingga lantai ruang pamer penuh dengan lukisannya dan hasil karyanya. Pamerannya

\section{UPT Perpustakaan ISI Yogyakarta}


tidak hanya berskala nasional tetapi sudah mencapai pameran tingkat internasional di berbagai negara. Di di Indonesia pamerannya juga pernah dilibatkan pada film Ada Apa Dengan Cinta 2, yang semakin membuatnya dikenal oleh masyarakat umum.

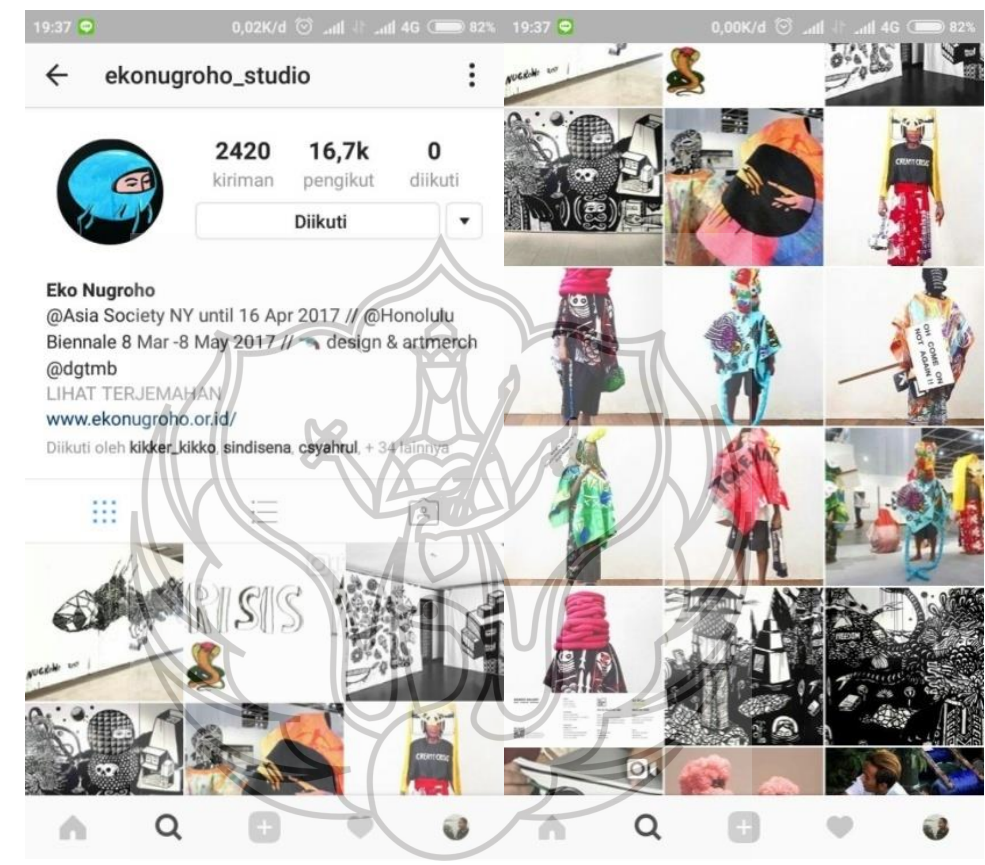

Gambar 1. Tampilan akun Instagram milik Eko Nugroho Sumber: akun instagram Eko Nugroho diakses tanggal 28 Maret 2017 pukul 14.32 WIB

Eko Nugroho juga salah satu seniman yang aktif menggunakan media sosial Instagram untuk berbagi karya-karya yang merupakan hasil kreatifitasnya. Seluruh fasilitas Instagram Eko Nugroho manfaatkan dengan maksimal, seperti menggunggah foto, video, siaran langsung, dan instastory. Memperlihatkan karya-karya dan aktivitasnya di Instagram

\section{UPT Perpustakaan ISI Yogyakarta}


membuat para pengapresiasinya merasa lebih dekat dengannya. Setiap hari pengikut akun Instragamnya selalu meningkat. Berdasarkan latar belakang tersebut maka penulis tertarik untuk melakukan penelitian dengan judul "Aplikasi Instagram Dalam Meningkatkan Eksistensi Eko Nugroho".

\section{B. Rumusan Masalah}

Setelah mengetahui latar belakang masalah, terdapat dua rumusan masalah yang akan dibahas dalam penelitian ini, yaitu:

1. Bagaimana strategi publikasi yang digunakan Eko Nugroho dengan aplikasi Instragam?

2. Bagaimana respon masyarakat terhadap karya-karya dalam media Instagram Eko Nugroho?

\section{Tujuan dan Manfaat}

1. Tujuan

Tujuan dari penelitian ini adalah sebagai berikut:

a. mengetahui strategi publikasi yang digunakan Eko Nugroho memamerkan karya-karyanya melalui aplikasi Instragam

b. mengetahui bentuk apresiasi masyarakat terhadap karya-karya Eko Nugroho dalam media Instagram

2. Manfaat

Manfaat yang akan diperoleh dari penelitian ini adalah:

\section{UPT Perpustakaan ISI Yogyakarta}


a. Menambah pengalaman di media sosial mengenai eksistensi seniman

b. Bisa digunakan untuk referensi para seniman untuk memaksimalkan penggunaan instagram sebagai pendongkrak ekstistensi

\section{Hipotesis}

Pengertian hipotesis penelitian menurut Sugiyono dalam bukunya Statistika Untuk Penelitian adalah sebagai berikut:

"Hipotesis merupakan jawaban sementara terhadap rumusan masalah penelitian, di mana rumusan masalah penelitian telah dinyatakan dalam bentuk pertanyaan. Dikatakan sementara karena jawaban yang diberikan baru didasarkan pada teori. Hipotesis dirumuskan atas dasar kerangka pikir yang merupakan jawaban sementara atas masalah yang dirumuskan."

Dari penjelasan di atas, maka jawaban sementara dari penelitian ini adalah berdasarkan pengamatan bahwa media Instagram memberikan informasi yang luas, dan Eko Nugroho secara konsisten, strategis, dan efektif memanfaatkan media tersebut, maka dapat diduga akan meningkatkan eksistensi Eko Nugroho sebagai seniman yang mendunia.

\section{E. Metode Penelitian}

Berdasarkan permasalahannya, penelitian ini menggunakan metode deskriptif analisis dengan memanfaatkan data kualitatif dan observasi data secara kuantitatif. Bogdan dan Taylor mendefinisikan metodologi kualitatif sebagai prosedur penelitian yang menghasilkan data deskriptif berupa kata-kata tertulis

\footnotetext{
${ }^{7}$ Sugiyono, Statistika untuk Penelitian, Bandung : Penerbit Alfabeta, 2009, hal.96
}

\section{UPT Perpustakaan ISI Yogyakarta}


atau lisan dari orang-orang dan perilaku yang dapat diamati. ${ }^{8}$ Dalam Proses penelitian secara kualitatif dilakukan dengan beberapa tahap sebagai berikut:

\section{Pengumpulan Data}

Dalam melakukan penelitian terdapat langkah-langkah sistematis yang harus dilakukan. Hal ini berupa penerapan metode ilmiah dalam penelitian, yang bertujuan hasil penelitian dapat dipertanggung jawabkan kebenarannya. Dalam penelitian ini pendekatan penelitian yang dilakukan adalah melalui pendekatan studi kasus. Data kuantitatif melalui kuesioner diperlukan sebagai penguat analisis kualitatif.

a. Studi Pustaka

Dalam penelitian kualitatif pengumpulan data dilakukan studi pustaka berupa referensi buku-buku dan artikel-artikel yang mendukung penelitian dan pengumpulan data lebih banyak pada observasi berperan serta (participant observation).

b. Observasi Instagram

Dalam observasi Instagram akan dilakukan pendataan terhadap respon masyarakat. Observasi akan dilakukan secara kuantitatif untuk mengetahui jumlah pengikut dan pemberi tanda suka disetiap unggahan foto.

${ }^{8}$ Prof. Dr. Lexy J. Moleong, M. A., Metodologi Penelitian Kualitatif, Bandung: PT. Remaja Rosdakarya, 2012, hal. 4.

\section{UPT Perpustakaan ISI Yogyakarta}


c. Wawancara

Penelitian ini menggunakan wawancara semi terstruktur, jenis wawancara ini sudah termasuk dalam kategori wawancara mendalam (in dept interview) yang dalam pelaksanaanya lebih bebas bila dibandingkan dengan wawancara terstruktur. Tujuan dari wawancara ini adalah untuk menemukan permasalahan secara lebih terbuka. Wawancara akan dilakukan pada narasumber, diantaranya Eko Nugroho sebagai seniman rupa yang akan diteliti, beberapa dosen perguruan tinggi seni di Indonesia, dan kuesioner respon dari responden.

2. Analisis Data

Analisis data merupakan kegiatan setelah data dari seluruh responden atau sumber data lain terkumpul. "Analisis dapat dilakukan dengan cara mengelompokkan data berdasarkan variabel dan jenis responden, menyajikan data tiap variabel yang diteliti, dan melakukan analisis untuk menjawab rumusan masalah". 9

3. Penyusunan Laporan

Penyusunan laporan dapat dilakukan melalui studi pustaka, analisis data, pengolahan data disusun secara sistematis dalam format penulisan skripsi, sehingga terbentuk laporan tugas akhir.

${ }^{9}$ Sugiyono, Metode Penelitian Kuantutatif, Kualitatif, dan R\&D, Bandung:Penerbit Alfabeta, 2011, hal. 147.

\section{UPT Perpustakaan ISI Yogyakarta}




\section{F. Sistematika Penulisan}

Sistematika pada penulisan karya tulis Aplikasi Instagram Dalam Meningkatkan Eksistensi Eko Nugroho akan teridiri dari beberapa bab:

- BAB I yang berisi tentang latar belakang

- BAB II yang akan menjelaskan tentang landasan teori yang mendukung penelitian ini.

- BAB III berisi tentang data dan analisis data yang menjawab rumusan masalah, hipotesa, dan hasil wawancara dengan Eko Nugroho.

- BAB IV berisi kesimpulan dan saran.

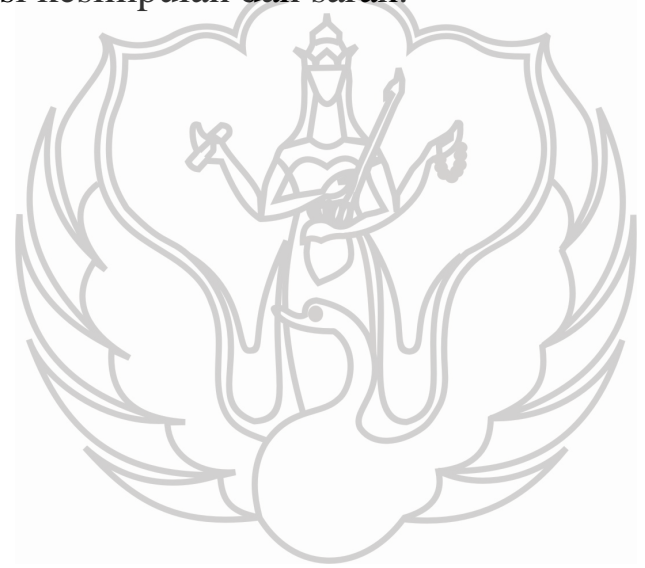

\section{UPT Perpustakaan ISI Yogyakarta}

